\title{
HEROIC EPOS OF NORTH CAUCASUS NATIONS AS BASIS FOR ETHNICAL CULTURE OF ADYGEA PEOPLE
}

\author{
N. Vigel, l. Zholobova \\ Rostov state medical university \\ Rostov-on-Don, Russian Federation \\ science-almanac@mail.ru
}

The current socially-political situation induced the representatives of various knowledge spheres to pay a special attention to customs, manners and traditions of North Caucasus people, to peculiarities of their spirituality and culture. The significant interest to mythology, religion, epos and intercultural interaction of various ethnical communities is connected not only with a demand in the culture dialogue, in contact points establishment in modern society multicultural space, but also with necessity of foundations search for spiritual and moral upbringing of the rising generation. Oral poetical creation is a unique and rich source of cultural self-determination. Study of epical heritage is a significant constituent of upbringing in the spirit of regardful and tolerant attitude, opposition to nationalism and xenophobia in multinational government. Narts heroic epos, to analysis of which a lot of scientific works of various knowledge spheres specialists are dedicated to (ethnographers, philologists, culturologists, philosophers and sociologists) is considered to be the fundamental monument of oral folk art in the North Caucasus.Heroic epos "Narts", referred to culturally-historical heritage of Adygea inhabitants, as the brightest phenomenon of their spiritual culture, gives possibility to come to consideration of ethno-specific values and ideals, allowing to speak about hero phenomenon, whose supertemporal and supracultural character is incontestable. An epic hero, being the bearer of a row of qualities, separating him from the number of majority of qualities and characteristics, virtually, represents some "archetype" - extra-significant suggestive image of cultural space. The actions performed by him are considered as heroic, and pass to the category of achievements, but locality and subjects, connected with them acquire a ritual, sacred character. The epos "Narts", ancient monument of Adygea culture, defined heroic-epical traditions of Adygea people, the hero has those features, which are the most valuable, ethno-specific and allow him to survive in the mountain severe conditions. At the same time a lot of them are considered to be universal, generally-cultural and socially-significant, especially in the modern society. The question is about such moral qualities, as humanity and honesty. Nart epos also reflects specific peculiarities of a genuine "Nart person", as a warrior, possessing several languages, honest, smart and sagacious, knowing enough information about traditions and way of life of neighboring people, hospitable, capable to estimate and admit advantages of any person even an enemy. Mainly these moral traditions comprise that valuable basis, which allows speaking about traditional culture of Adygeya people, reproduction of archaic values in modernity, about upbringing bases in this culture and that spiritually-moral potential, which it bears in itself.

Key words:Adygea people, archetypical image, spiritual culture, spiritually-moral potential, myth, "Narts", epic hero, epos.

[Вигель Н.Л., Жолобова И.К. Героический эпос народов Северного Кавказа как основа этнической культуры Адыгов]

Сложившаяся в настоящий момент социально-политическая ситуация побудила представителей различных областей знания обратить особое внимание на обычаи, нравы и традиции народов Северного Кавказа, на особенности их духовности и культуры. Значительный интерес к мифологии, религии, эпосу и межкультурному взаимодействию различных этнических общностей связан не только с потребностью в диалоге культур, в установлении точек соприкосновения в поликультурном пространстве современного общества, но и с необходимостью поиска оснований для духовного и нравственного воспитания подрастающего поколения. Уникальным и богатейшим источником для культурного самоопределения является устное поэтическое творчество. Изучение эпического наследия народов является важной составляющей воспитания в духе уважительного и толерантного отношения, противодействия национализму и ксенофобии в многонациональном государстве. Фундаментальным памятником устного народного творчества на Северном Кавказе является нартский героический эпос, анализу которого посвящено множество научных работ специалистов из различных областей знания 
(этнографов, фрилологов, культурологов, философров и социологов).Героический эпос «Нарты», относящийся к культурно-историческому достоянию адыгов, как наиболее яркий феномен их духовной культуры, дает возможность подойти к рассмотрению этно-специфических ценностей и идеалов, позволяющих говорить о френомене героя и героического, надвременный и надкультурный характер которого неоспорим. Эпический герой, будучи носителем ряда выделяющих его из числа большинства качеств и характеристик, по сути, представляет собой некий «архетип» - сверхзначимый суггестивный образ культурного пространства. Совершаемые им деяния признаются героическими, переходят в разряд подвигов, а связанные с ними местность и предметы приобретают ритуальный, сакральный характер. В эпосе «Нарты», древнейшем памятнике адыгской культуры, определившем героикоэпические традиции адыгов, герой несет в себе те черты, которые наиболее ценны, позволяют ему выжить в суровых условиях гор, этноспецифичны. В то же время мы находим многие из них универсальными, общекультурными и социально значимыми, особенно в современном нам обществе. Речь идет о таких нравственных качествах, как человечность и порядочность. Нартовский эпос отражает и специфические особенности истинного «нарта» как владеющего несколькими языками воина, правдивого, умного и сметливого, знающего достаточно сведений о традициях и быте соседних народов, гостеприимного, способного оценить и признать достоинства любого, даже врага. Именно эти нравственные традиции составляют ту ценностную основу, которая позволяет говорить о традиционной культуре адыгов, воспроизводстве архаических ценностей в современности, об основах воспитания в этой культуре и том духовно-нравственном потенциале, который она в себе несет.

Ключевые слова: адыги, архетипический образ, духовная культура, духовно-нравственный потенциал, миф, «Нарты», эпический герой, эпос.

Narine L. Vigel - Ph.D., professor. Rostov state medical university. Rostov-on-Don, Russian Federation. Irina K. Zholobova - assistant. Rostov state medical university. Rostov-on-Don, Russian Federation.

ВигельНаринеЛипаритовна - докторфилософскихнаук, професссор. Ростовский государственный медицинский университет. г. Ростов-на-Дону, Россия.

Жолобова Ирина Константиновна - ассистент. Ростовский государственный медицинский университет. г. Ростов-на-Дону, Россия.

The modern researchers more often incline to the notion of globalization as to the project, which is interpreted in the abstract-philosophical way. These lines can be clearly seen in informational, sociological, cultural way. Formation of "Big society", stimulating integrative processes is considered to be inexorable factor. The question about scheme production of various systems interconnection for the changing society, interconnection standards formation between various sociocultural communitiesappears to be methodologically significant aspect of postclassical paradigm.

The current transition to priority of panhuman values conditions such careful attention to cultural heritage of people, aspiration to rethinking and overestimation of its role and significance in the modern society. Thus, from the beginning of XXI century renewed interest to national sources, secular customs and traditions, oralfolk art can be observed, the search of universal constituents of mentality, capable to become psychological and ideologicalbasis of interethnic dialogue is continued[7].Analysis and understanding of "traditional" cultures axiological, spiritual potential, understanding of people cultures as integral and united,possibilities of reception of modern culture ethnical norms is admitted as methodological principle.

Epic ancient works are an original ideological heritage, reflecting formation and development peculiarities of ethnos in the defined period of time. There images, motives of national culture and accompanying them values are discovered.Epos creation is often understood as "spiritual unity of collective consciousness, where knowledge practically always ornamented with mythological views" [10, p. 265]. Myths are considered to be the most important source of heroic epos formation, especially mythological legends about ancestors - cultural heroes. 
Myth - not only the system of "knowledge" or "culture", is something more according to the influence on human life. Myth filled practically all cogitative, emotionally-volitional and practically-vital "space". One should begin to reveal myth's significance from its definition. Myth narrates, how reality, thank to achievements reached its implementation and realization, this is a story about some "creation". He speaks only about really happened things, about something that manifested itself to the full. Myth's personages - commonly known heroes, who act in legendary times, myth narrates their creative activity, sacredness or superhumanityof their actions.

Epos of this or that people like a myth represents heroic narration, symbolically, by means of archetypical images reflecting ethnos world perception, its ideas about world, its origin and development, about gods and a human, about heroes, whose names and achievements are passed on from generation to generation. Heroic epos as a complex phenomenon of archaic national culture allows reflecting values and ideals in the epic form, and also aspirations and expectations of people.This is the richest spiritual experience of humanity, where striving "on the level of mythoepic consciousness to connect myths of collective, cosmic, social, panhuman and individual, personal to some harmony" is retraced[10, p. 271].

Nart heroic epos is a property not of some certain people or even a group of relative people, but a whole conglomerate differed in peculiarities of emersion and development, confession of Caucasus people. According to the whole row of the researchers (P.Autlev, M.Talpa, I.Treskov, A.Shortanov) the peculiarity ofNartiad is that despite the proximity ofmythoepic material content (they are united by beauty admiration, love and devotion to their people, bravery of heroes), conditioned by ethnical originality specific cultural features can be observed in its ethnical versions. Correspondingly every nation in the North Caucasus has its own variant of Nart heroic epos. One should admit the necessity of myths, Nart legends and other forms of folk art consideration, and also cultural images in the corresponding historically-cultural context.

Such researchers as V. Abaev, A.Gutov, Zh.Dyumezil, M.A. Kumakhov point to the presence of protoculture elements of Adygea people, currently comprising one of the biggest ethnographic group of the North Caucasus, in the Nart heroic epos."The ancient heroic epos "Nartkher" is appeared to be the basic folk monument, which implies the complex of original Adygea national songs, unique poems and legends about Nart heroes" [9, $p$. 199]. The ancient Adygea heroic epos "Narts" is considered to be one of the most important cultural formations ofAdygea ethno-historical reality, conditioned heroic-epical traditions of Adygea people, their ideas about hero and heroicquality. This epos stands in one row with the greatest creations of the world culture, this is indisputably the most valuable thing from that, created in past and preserved by the Adygea people folk art.

It is important to note that the word Nart (nat) is ambiguous in functional relation as it appears to be the general under the denomination of all central personages of Nart epos. As a rule, the heroes of ancient epical legends - magic warriors-heroes are understood under the Narts.In the row of late Nart legends of Adygea people one can see the relations alteration between epical heroes and epos creators, which are expressed in their contradiction as representatives of generations, changing each other. Correspondingly, AdygeapeoplecometoreplacetheNarts.

Generally, the Adygea people culture, and also mythoepical one, is oriented to "...proclamation of a free, integral, active and heroic person as the highest value" [10,p. 269]. The altitude, expressed in the symbolics of a mountain or star altitude is considered to be the moral orienting point of ancient epos "Narts" heroes. The legend about a hero, who after overcoming a mountain peak, obtained fire for the freezing compatriots, can serve as a private example. 
In the course of considered heroic epos text analysis a whole row of reflecting archaic religious-mythic ideas images, archetypes, universal symbols, uniting people ofthe whole world and testifying about their connection, can be emphasized. Thus, in the "cycle of epic legends, comprising the nucleus of Adygea epos and full of mythological elements, Narts resist to giants, chthonian monsters, having the wide typological parallels in the monuments of archaic epos ofmany people"[8, p. 33].The content of panhuman values and based on them behavioral models, certainly, having specific cultural peculiaritiesis considered to be the most important. Primarily one speaks about regardfulattitude to the own history, veneration in front of immortal achievements of ancestors, cultural heroes, reverence to the old people.

Nart epos is rich with stable archetypical images, symbols of Adygeyapeople epicalmemory, reflecting peculiarities of consciousness and world perception of Adygeya people. Though, as it was already told earlier, it is also easy to emphasize those features and images, which bring together culture of people with other cultures."Motives and personalized images of several cultural archetypes are easy to trace in the Adygeya epos. The archetype of the Great Mother, appearing to be unconscious expression of feminine origin and principle in the culture and society, is embodied in the epical image of the Mother of all the Narts, progenitorof Satanei life (Setenei), ... archetype of the Hero, whose characteristic attributes obtained personification in the mythoepic character of Sosruko" [10, p. 271].Ashemeza, Badynoko and Totresh are referred to the number of Adygea epos heroes besides Sosruko.

There one speaks about lonely heroes as universal images, existing in unconscious collective of a person, the activity of whom "in culture reality reflects separate features of the highest essence ofa person...the internal world recreation, reformation of completed social existence, direction of its personal and culturally- revolutionary potential to the outside world, its recreation inside itself " [10, p. 270]. The main heroes-Narts were gifted with soul nobility and perfect intelligence, performed actions, the significance and value of which areinvariable over a period of many centuries.

A person, possessing several languages, and also who was honest, smart, unselfish and sagacious warrior, knowing enough information about traditions and living conditions of neighboring people, hospitable and capable to estimate and admit advantages of any person, and even an enemy was considered to be the genuine Nart, that is to say the son of the sun.Fine manners, decency, modesty and of course humanity are first of all the differential characteristics of them. The epos heroes follow moral and ethical postulates in their behavior. A person who did not follow these rules, and broke them, was despised and proclaimed as an alien.Severe upbringing accustomed them to resist intense heat and cold in the mountains and experience trials and privations without grumble.

Presently the upbringing and education system should be mainly oriented to training of a physically healthy and spiritually sound person The obtained scientific and research material in the course of study of heroic epos should be actively used in multicultural education of the students. On the example of the heroic epos "Narts", which counts thousands of years, one can see what a significant role can be played by the cultural heritage in the upbringing of many generations of young people.It is also important to mention that besides heroic epos Adygea people appear to be heirs ofthe national artistic culture richest layer. These are legends, parables, historically-heroic songs, fairy tales, proverbs and sayings. " Undoubtedly that such cultural heritage can render an invaluable service in formation of national and historical consciousness of modern Adygea people, culture of international communication" [9, p. 199]. One speaks not only about rebirth of the North Caucasus people national cultures and possibility to improve their relations, connected with their general invaluable cultural heritage, but also attention drawing to the panhuman values as an important constituent of upbringing in the spirit of regardful and tolerant relation, opposi- 
tion to nationalism and extremism [3, p. 35; 4, p. 101; 6].The conducted culturally-historical analysis allows speaking that epical pieces of work of the past still represent the richest material for research by the contemporaries.

Heroic epos, particularly "Narts", appears to be the reflection of cultural ideals and values, contains the story about achievements, about characteristic qualities of heroes that is very important in upbringing of rising generations, in orientation them to heroic actions, inaspiration to similarity with a hero. The life of a hero is represented in heroic epos as a triumph of spirit and achievement.Heroes, accordingly, are those few people, who "overcome the disease of time" and "break to the eternity".A person could exist only when he ceased "being himself" and "reproduced" the sample. A person's idea of himself has not formed yet and has being formed through "the other". Imitation of heroic actions, repetition of deeds, initially committed by the heroes, removes the life concernment and forms the way of a person. The implication experience, expressed in united knowledge, in practicallyvital, emotionally-sensual and volitional aspiration of the North Caucasus people becomes the tool for epomythical way of life of Narts. Evidently, that study of people heroic epos plays a special role in multicultural upbringing of the modern youth, in formation of tolerant, regardful attitude to cultural peculiarities of other ethnical communities representatives, contributes to topical culture dialogue problem solving.

\section{Лumepamypa}

1. Агеева Н.А. Этико-правовой аспект невежества // Гуманитарные и социальные науки. 2014. № 2.

2. Буркина Л.С., Петренко Р.А., Петренко Е.А., Жолобова И.К. Социальная девиантность как культур-антропологический феномен. Ростов-на-Дону, 2013.

3. Вигель Н.Л. Толерантность как общечеловеческая ценность // Гуманитарные и социально-экономические науки. 2015. № 2 (81).

4. Вигель Н.Л. Проблема диалога культур в современности // Экономические и гуманитарные исследования регионов. 2015. № 4.

5. Камалова О.Н., Жолобова И.К. Основные тенденции и инновации в системе отечественного образования // Гуманитарные и социальные науки. 2016. № 1.

6. Жолобова И.К., Камалова О.Н., Мустафраева З.С. Проблема фрормирования коммуникативной толерантности студентов высших учебных заведений // Гуманитарные и социальные науки. 2017. № 3.

7. Катеринич О.А., Петренко С.П., Мустафраев Ф.М. Этносфера и проблемы межкультурной коммуникации. Ростов-на-Дону, 2013.

8. Кумахов М.А., Кумахова З.Ю. Нартский эпос: язык и культура. М., 1998.

9. Кускарова О.И. Эпос «Нарты» как источник культурно-этнического наследия адыгов: философрский аспект // Нартоведение в 21 веке: проблемы, поиски, решения: Материалы Международной научно-практической конференции. Магас, 2016.

10. Хоконов М.А. К проблеме фрилософско-культурологического осмысления адыгского нартского эпоса // Нартоведение в XXI веке: современные парадигмы и интерпретации: Сборник научных трудов. Владикавказ, 2012.

\section{References}

1. Ageeva N. Ethics-juridical aspect of ignorance // Humanities andsocial sciences. 2014. No 2. 
2. BurkinaL., PetrenkoR., Petrenko E., Zholoboval.Social deviant activities as culture-anthropological phenomenon. Rostov-on-Don, 2013.

3. Vige/N.Tolerance as panhuman value // Humanities and social sciences. 2015. No 2 (81).

4. Vigel N.The problem of cultures dialogue in modernity // Economic andhumanitarian researchesof the regions. 2015. No 4.

5. KamalovaO., Zholobova I.The basic tendencies and innovations in the system of domestic education // Humanities and social sciences. 2016. No 1.

6. Zholobova I., KamalovaO., MustafaevaZ.The problem of students communicative tolerance formation of higher educational institutions//Humanities and social sciences. 2017. No 3.

7. KaterinichO., PetrenkoS., MustafaevF.Ethnosphere and the problems of intercultural communication. Rostov-on-Don, 2013.

8. KumakhovM., Kumakhova Z.YNartepos: language and culture. M., 1998.

9. KuskarovaO.Epos"Narts" as a source of culturally-ethnical heritage of Adygea people: Philosophical aspect // Nart study in 21 century: problems, search, decisions: Materials of theoretical and practical conference. Magas, 2016.

10. KhokonovM.To the problem of philosopho-culturological understanding of Adygea Nart epos // Nart study in XXIcentury: modern paradigms and interpretations: Collection of scientific papers. Vladikavkaz, 2012. 